\title{
Sustainable Development Goals - Quo Vadis, Cities of the World?
}

\section{Cele zrównoważonego rozwoju - dokąd zmierzają miasta?}

\author{
G Venkatesh
}

\author{
Department of Chemical and Engineering Sciences, Karlstad University, \\ Karlstad, Sweden - 65188 \\ E-mail: Venkatesh.govindarajan@kau.se, ORCID: 0000-0003-3347-7262
}

\begin{abstract}
The United Nations unveiled a set of 17 Sustainable Development Goals (SDGs) in September 2015, with 169 targets and a little over 230 indicators. This was a sequel to the Millennium Development Goals whose remit ended in 2015. Challenges lie ahead for governments around the world - national, provincial and municipal - to adapt the targets and indicators to effect a meaningful transition towards sustainable development by 2030. Cities are where the battle for sustainable development will be won or lost - they contribute $80 \%$ of the global GDP, and account for $70 \%$ each of global energy consumption and greenhouse gas emissions. With over two-thirds of the global population likely to live in cities by 2060 , this is more than a cliché. A clutch of sustainable cities makes a sustainable province; a clutch of sustainable provinces makes a sustainable country, and it follows that several sustainable countries learning and sharing and helping other countries, will make for a sustainable world in the 21 st century and further on into the future. While moving forward, trade-offs and complementarities must not be forgotten. Often, there are serendipitous benefits when complementarities which exist are not factored in, but the trade-offs if forgotten may end up robbing Peter to pay Paul. Despite the interregnum brought about by the Corona Virus pandemic in 2020, the world will be getting up, dusting itself clean and moving ahead in the next decade towards the SDGs set for year-2030.
\end{abstract}

Key words: Sustainable Development Goals, Millennium Development Goals, Targets, Indicators, Urban sustainability

\section{Streszczenie}

Organizacja Narodów Zjednoczonych we wrześniu 2015 r. uchwaliła zestaw 17 Celów zrównoważonego rozwoju (SDGs), obejmujących 169 podcelów i nieco ponad 230 wskaźników. Była to kontynuacja Milenijnych Celów Rozwoju, których misja zakończyła się w 2015 r. Władze na całym świecie - krajowe, prowincjonalne i miejskie - stoją przed wyzwaniem, aby dostosować cele i wskaźniki, aby dokonać znaczącego przejścia w kierunku zrównoważonego rozwoju do $2030 \mathrm{r}$. Miasta odgrywają kluczową rolę w bitwie o zrównoważony rozwój - niezależnie czy zostanie ona wygrana czy przygrana - bowiem tworzą $80 \%$ światowego PKB i odpowiadają za $70 \%$ globalnego zużycia energii i emisji gazów cieplarnianych. Ponieważ do 2060 r. ponad dwie trzecie światowej populacji będzie mieszkać w miastach, jest to więc oczywiste. Grupa zrównoważonych miast tworzy zrównoważoną prowincję; Grupa zrównoważonych prowincji tworzy zrównoważony kraj, a wynika z tego, że kilka zrównoważonych krajów zdobywających doświadczenie, udostępniających je innym krajom oraz pomagających im, stworzy zrównoważony świat jeszcze XXI wieku i dalej na przyszłość. Idąc naprzód, nie można zapominać o kompromisach i komplementarnościach. Często pojawiają się nieoczekiwane korzyści, gdy komplementarność, która istnieje, nie jest uwzględniana, ale kompromisy, jeśli zostaną zapomniane, mogą skończyć się okradaniem Piotra, aby zapłacić Pawłowi. Pomimo bezkrólewia wywołanego pandemią koronawirusa w $2020 \mathrm{r}$. świat będzie się podnosił i posuwał naprzód w kierunku Celów zrównoważonego rozwoju wyznaczonych na rok 2030.

Slowa kluczowe: Cele zrównoważonego rozwoju, cele, Milenijne cele rozwojowe, wskaźniki, zrównoważoność miejska 


\section{Introduction}

Sustainability refers to a state, or an ability. Sustainable development is a process. This process is essentially the means towards the end, which is sustainability itself. Here, it is necessary that the means - the process of development and all that it entails - are sustainable, in order to justify the end. As said in Kallio, et al. (2007), the phenomenon we label as sustainable development can never be exhaustively defined; it would constantly change with time, interpreters and their needs. We thus have an elusive, impermanent end-goal, which is pursued with a changeable set of ways and means. Quental, et al. (2011) has stated that the introduction of sustainable development as a concept was an intellectual answer to reconcile the conflicting goals of environmental protection and economic growth.

\section{Space, time and just about everything}

When we talk of sustainability, as it is a moving target, the process of sustainable development needs to keep going on. It is never completed! Thus, the temporal aspect here suggests that while long-term thinking needs to be adopted, the process never really stops. It is quite like a never-ending relay race, with the baton changing hands, and the demands fluctuating, with sustainability being the constantlyreceding goal which a team of countless athletes, keep pursuing in turn. The degree of sustainability in other words, is the prevalent status at any point of time, and if sustainability is always a moving target, this degree will never be $100 \%$. As far as the spatial aspect is concerned, we are all connected, through the atmosphere, hydrosphere and pedosphere, and the anthropospheric constructs of trade and travel. What I do now, may/can/will impact someone else somewhere adversely or favourably. If space and time are considered together, this someone else somewhere, may even be a person who is not even born at the time of the deed. In other words, is it possible to ensure that someone somewhere at some point of time in the future is not adversely affected by what I do here now?

City-level decision-makers are faced with the almost-insurmountable challenge of integrating seemingly-conflicting disciplines and adopting a holistic, balanced, and sustainable approach to the policies they draw up, to make the path towards the elusive goal more tractable. The mere awareness and the readiness to understand the importance of sustainable development opens the mind up to question, criticize, challenge, learn, unlearn and relearn.

\section{The SDG framework prescribed by the United Nations}

That brings us to the Sustainable Development Goals (SDGs) unveiled by the United Nations in Septem- ber 2015, as a sequel to the Millennium Development Goals (MDGs). There are seventeen of them, each with a set of targets, and each target defined by a range of indicators.

While the categorisation in Table 1 has been done by the author, Ho and Goethals (2019) have defined the 5Ps - People (SDGs 1, 2, 3, 4, 5); Planet (SDGs 6, 12, 13, 14 and 15); Prosperity (7,8,9,10 and 11), Peace (SDG 16) and Partnership (SDG 17). The measures for the indicators may be quantitative, qualitative or semi-quantitative. In many cases, lack of measurable data can be compensated for, by having a qualitative description of the performance; or a Likert's scale ranking in lieu of actual indicator values. It must be pointed out here that everything cannot be quantified and often, contextually-important indicators representing the softer aspects of sustainable development, are necessarily qualitative or at best, semi-quantitative. The total number of SDGtargets is a whopping 169 (an average of 10 per SDG), which perforce needs to be whittled down to a manageable, workable, measurable and transparent set of targets, to concentrate minds and facilitate easier and effective decision-making. Performance towards each of these targets is measured with the aid of one or more indicators, bringing the total number of indicators defined for the SDGs to 232 (of these nine are repeated across targets/goals twice or thrice). For the sake of comparison, one may add at the end of this sub-section that the MDGs were 8 in number (vis-à-vis the 17 SDGs), and in contrast to the maximum of 169 targets identified under the 17 SDGs, there were just 60 under the 8 MDGs.

More targets/indicators need not always be merrier. Less may not always be advisable. While these two quantitative adjectives introduce more confusion than clarity, a via media is smart - an acronym for qualitative adjectives: specific, measurable, attainable, relevant and time-bound. According to Zondervan (2017), the International Council of Science and the International Social Science Council, have observed that of the 169 targets, 49 are welldeveloped, 91 could be strengthened by being more specific and the remaining targets require significant work.

\section{Applications at different levels - thus far}

Zinkernagel et al. (2018) is a rich source of literature references which help in understanding how opinions and suggestions about, and knowledge of sustainable development goals have proliferated over time. There are voluntary official government-led national reviews of SDGs - most of them are narrative in style and focus on institutional processes, consultations, and challenges without providing an evidence-based quantitative assessment of national progress against the SDG targets and indicators (Allen et al., 2018). One does find applications at 
Table 1 . The SDGs categorised based on the three pillars of sustainability (categorisation done by the author)

\begin{tabular}{|c|c|c|c|c|}
\hline Category & SDG & Name & Targets & Indicators \\
\hline \multirow[t]{5}{*}{ Social } & 2 & Zero hunger & 8 & 14 \\
\hline & 3 & Good health and well-being & 13 & 24 \\
\hline & 4 & Quality education & 10 & 11 \\
\hline & 5 & Gender equality & 9 & 14 \\
\hline & 10 & Reduce inequalities & 10 & 11 \\
\hline Economic & 9 & Industry, innovation and infrastructure & 8 & 12 \\
\hline \multirow[t]{3}{*}{ Environmental } & 13 & Climate action & 5 & 7 \\
\hline & 14 & Life below water & 10 & 10 \\
\hline & 15 & Life below land & 12 & 14 \\
\hline \multirow[t]{2}{*}{ Socio-economic } & 1 & No poverty & 7 & 12 \\
\hline & 8 & Decent work and economic growth & 12 & 17 \\
\hline Economic-environmental & 7 & Affordable and clean energy & 5 & 6 \\
\hline Socio-environmental & 6 & Clean water and sanitation & 8 & 11 \\
\hline \multirow[t]{2}{*}{ Encompassing all three dimensions } & 11 & Sustainable cities and communities & 10 & 15 \\
\hline & 12 & Responsible production and consumption & 11 & 13 \\
\hline \multirow[t]{3}{*}{ Governance/Political will } & 16 & Peace, justice and strong institutions & 12 & 23 \\
\hline & 17 & Partnerships for the goals & 19 & 25 \\
\hline & & Total & 169 & 232 \\
\hline
\end{tabular}

sub-national-levels (provincial or state-level) in literature, though city-level comprehensive applications of the SDG framework are yet to be firmly entrenched in decision-making. During the last two decades (more specifically, from 1993 to 2015) there have been many attempts by international organisations and cities themselves, as well as private and interest groups, to develop indicators and indicator sets to monitor cities' sustainable development, accompanied by a proliferation of different monitoring methods. While the SDGs were launched by the UN in 2015, planning and performance monitoring has been guided by several sets of indicators, as referred to earlier - starting from the UN Habitats Urban Indicator Programme (1993) to the Commission for Sustainable Development's Sustainable Development Indicators (1995), EU's sustainability indicators (1998) to European Common Indicators (2000) to OECD's Better Life Index (2011) to ISO 37120 indicators (Sustainable development of communities) (2014). The number of indicators ranged from 10 for the European Common Indicators set to 97 for the one launched in 2014. For cities which have been measuring their sustainability performance using one of these, transiting to the SDGs which indeed have a much wider and all-encompassing scope with a total of over 200 indicators, may be a desirable and sought-after change characterised by scepticism and confusion, which needs to surmounted. The indicator sets which preceded the SDG-set of 2015 are not perfect sub-sets of the latter. Some key indicators from the older sets are missing from the list of 232 which comprise the SDGs, and ought to have been included.

\section{Global Initiative for the UN - Cities in the USA and Europe}

While such efforts have provided the impetus needed, it will not be long before sustainable development evolves from being a fuzzy concept to something which can be operationalised despite (or rather thanks to) its multidimensional nature. The tradeoffs and hurdles which one refers to, will remain. They may not be entirely overcome in the near future, but once the ball is set rolling, benefits to decision-making will surely accrue; and changes when they happen, will be for the better. Two reports from 2019 (Lynch et al., 2019; LaFortune et al., 2019) outputs from A Global Initiative for the United $\mathrm{Na}$ tions, deserve mention at the outset. Also worthy of mention, additionally, is a report encompassing 1.3 billion people (more than the combined populations of the EU and the USA accounted for in the reports referred to in the previous sentence) - NITI Aayog (2018) - the SDG India Index baseline report for year-2018 does a statewise analysis for 13 of the 17 SDGs; hopefully providing an impetus for the laggards (the authors however would like to label them euphemistically as 'aspirants') to catch up with the frontrunners.

Lynch et al. (2019) as well as LaFortune et al. (2019) have excluded the SDGs 14 and 17 (refer to Table 1 ), owing to either data non-availability or irrelevance to the city-level analysis. The American analysis narrows down the range of indicators to $54 ; 41$ of these aligning with the State-level sustainability index calculated earlier; and 19 of these 41, figuring in the calculation of the national-level index. The authors emphasize that challenges are very diverse on local levels within even small countries, and hence 
sub-national (state-level, provincial level, city or town levels) efforts to gather data (disaggregation of national-level data in other words) are extremely important and effective and indispensable, if one may add in the last adjective to drive the importance home, for the attainment of the SD goals. It is even possible that mayors and decision-makers on citylevels may not find suitable indicators in the SDG framework to represent something which they think is vital and crucial to sustainable development within their domains. This would call for tailor-making the indicators (or defining modified ones) to make decision-making meaningful. In an assessment done for Australia (Allen et al., 2019), the authors of the said paper have categorised the indicators factored in, as original (as prescribed by the UN) alternative (minor variations on the original ones) and complementary (totally new ones defined contextually).

LaFortune et al. (2019) have observed that $65 \%$ of the SDG's targets (about 110 of the 169) can be reached only by working concertedly on local and regional scales. It follows that local leaders ought to be engaged in the exercise very closely, their viewpoints heard, and deliberations with the general public must not be dispensed with.

\section{SDG 11 and adapting the others to local context}

It is imperative to localise the targets and indicators of the other SDGs (other than SDG 11, that is) to strengthen their urban and local dimensions. The targets of SDG11 can also be considered as so-called composite targets, interlinked with targets set under other SDGs (Nicklin and Cornwell, 2019). SDG11 forms the basis for projects being undertaken by the Arab Bank for Economic Development in sub-Saharan African countries, in cities in, inter alia, Benin, Ivory Coast and Cape Verde. At this juncture, it would be relevant to point out that cities in India perform very poorly (SDG 11 index score for the country, based on targets related to housing, slums and waste management, is 39 out of a maximum of 100) vis-à-vis the targets set by the government of India for year-2030, as noted in the SDG India Index report (NITI Aayog, 2018)

Cities can be encouraged (or mandated) to assume responsibility for monitoring performance for a specified sub-set of localised goals and targets - the indicators used clearly being subjective, valuedriven and selected in concert with other stakeholders, and defining the prevailing social debates and priorities - and achieving the same, within the timeframe set. The word prevailing implies that while the relevance of the currently-defined goals, targets and indicators are likely to change over time; new indicators may also be defined as paradigm shifts happen in urban systems (for instance, not very long ago, the number of Internet connections per 100,000 inhabitants was not considered as a sustainability indicator).
As observed in a special report on India in The Economist (26-10-2019), freeing Indian cities to run their own affairs would cost very little but substantially boost the quality of life for millions of people. What applies to India, applies to all developing and transition economies.

\section{U4SSC Framework}

The United 4 Smart Sustainable Cities Framework (Convention for Biological Diversity et al. 2019) has published its own set of Key Performance Indicators, based on (and derived from) some of the targets in the SDG framework. This can be looked upon as an effectively-truncated set of indicators, numbering 91 (Refer Figure 1). This framework adopts the triple bottom line de rigeur and identifies six typologies of KPIs (Figure 1) - core smart, core sustainable, core structural, advanced smart, advanced sustainable and advanced structural. Digressing just a wee bit, the measurement of most of the smart KPIs are ICT-enabled (Information, Communication and Technology) and in this context, the suggestion of the Global e-sustainability Initiative (cited in Jones et al., 2017) that smart manufacturing, smart agriculture, smart buildings, smart mobility and smart energy could cut global GHGs by $20 \%$ by 2030 is noteworthy. It follows that when the implementation of the SDGs gets underway on a war footing, the ICTsector will be avail of a massive business opportunity (Heeks, 2016, cited in Jones et al. 2017).

The Environmental KPIs in the U4SSC framework encompass six SDGs (6, 7, 11, 13, 14, 15 and 16), and address 12 targets in all. While SDG 16 which has been categorised by the authors of this paper under the Governance/Political Will dimension of sustainable development, the others can be identified as pure or hybrid environmental SDGs, also from Table 1. The Economic KPIs encompass 9 SDGs $(5,6,7$, $8,9,11,12,16,17)$, and address 26 targets in all, while the Socio-cultural ones include 9 SDGs $(1,2$, $3,4,5,8,10,11$ and 16) and address 30 targets. There are 16 KPIs which are linked to (referenced to, in other words), multiple targets in the same or different SDGs.

\section{Planetary boundaries approach}

Rockström et al. (2009), proposed the planetary boundaries approach to sustainable development, which they admitted was not being introduced as a roadmap per se to sustainable development but, in the context of the human predicament in the Anthropocene era, as a first step in identifying 9 biophysical boundaries at the planetary scale (and thereby the local and regional scales, when one narrows down to manageable scales), within which humanity has the flexibility to choose a myriad of pathways for human well-being and development (the social and the eco- 


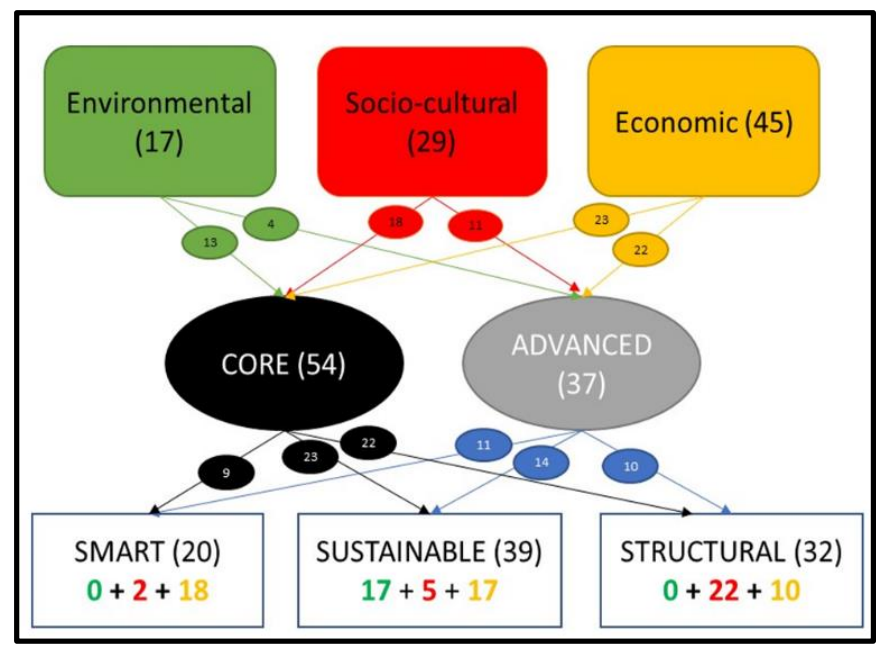

Figure 1. The KPIs in the United for Smart Sustainable Cities Framework, based on the SDGs (Convention for Biological Diversity, 2019)

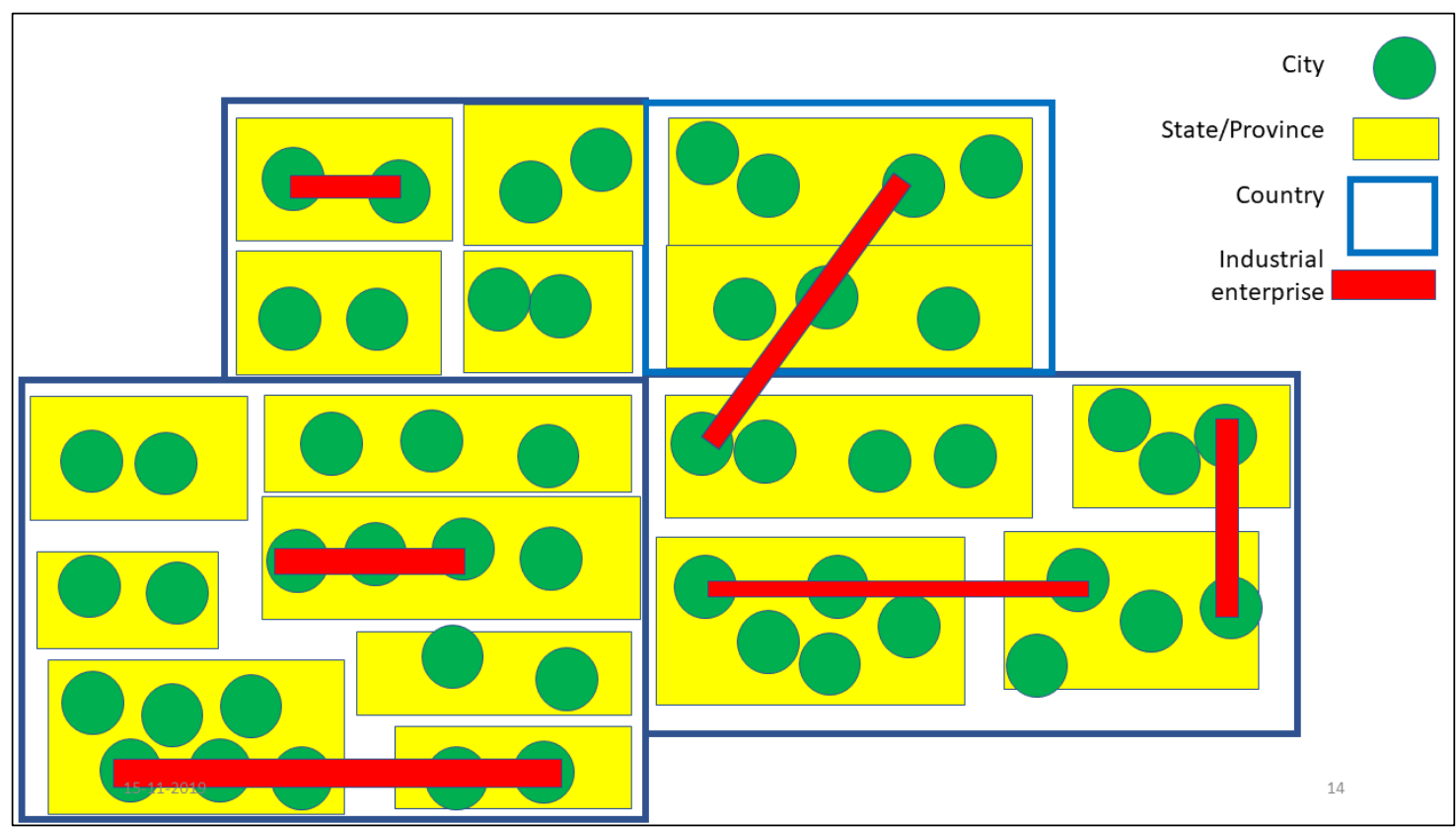

Figure 2. Schematic representation of cities, states, countries and industrial enterprises in a globalised world

nomic aspects in other words). As Pope Francis has long argued, care for the environment is inseparable from the fight against global inequality (in other words, SDGs 13, 14 and 15, are inseparable from SDG 5). The grand aim would thus be to enable 9 billion people to achieve the 17 SDGs, with the earth's 9 planetary boundaries in a safe state, by 2050. The authors categorise processes as systemic at planetary scale and aggregated at local or regional scales, and also as processes with and without known global scale thresholds. They however have chosen only one indicator per SDG (17 in all thereby) for their modelling. Cities influence all the processes discussed in the said paper - climate change, ocean acidification, stratospheric ozone depletion, global phosphorus and nitrogen cycles, atmospheric aerosol loading, freshwater use, land use change, biodiversity loss and chemical pollution, di- rectly or indirectly via the spillover effect (KlokeLesch, 2018). In the context of applicability of the SDGs to cities (the disaggregation which has been mandated by all sustainability researchers), it must be mentioned at this juncture that the PB framework is not designed to be downscaled or disaggregated to smaller levels, even though it recognises the importance of changes at the level of sub-systems (cities for instance) on the functioning of the earth as a whole.

On the indisputable premise that human prosperity and well-being (social and economic dimensions of sustainability) must be optimised within planetary boundaries set as guardrails to safeguard the environmental dimension, direct links (positive correlations - complementarities or negative correlations conflicts) between the improvements in the KPIs and ability of humankind to stay within the planetary 
boundaries As Steffen et al. (2015) have noted, climate change and biospherical integrity should be recognised as core planetary boundaries through which the other seven operate. It follows that a direct link between a KPI and a PB implies the presence of indirect links to the other PBs.

\section{Corporate level commitments to SDGs}

Harking back to a comment made earlier in this article, sustainability-thinking begins in the minds of individual citizens, extends to homes within cities, and through the process of learning and sharing, results in the mushrooming of smart, sustainable cities, states/provinces. Once a critical number of sustainable provinces is reached within a country, the laggards tend to follow suit. At the same time, the process of international learning and sharing (SDG 17), firmly entrenches the SSDGs on several national agendas, and the talk is walked. Referring to the schematic in Figure 2, one at once understands the inter-provincial and international nature of modernday industrial enterprises (be they in the primary, secondary or tertiary sectors). It follows that when multi-provincial and multinational corporates incorporate SDGs into their decision-making, they play a key role in contributing to sustainable development in many cities (and countries). In this era of globalisation however, even small players, by virtue of the fact that they have access to markets around the world, can influence far-flung sustainable consumption (Scott et al., 2019). In this Pricewaterhouse Coopers report, the authors analysed 729 companies in different industrial sectors (energy, utilities and mining - 95; financial services - 139; industrial products -182 ; technology, media and telecommunications - 124; retail and consumer - 124; transportation and logistics - 58) in 21 countries (Norway, Sweden, Netherlands, Germany, Belgium, Luxembourg, Romania, UK, France, Spain, Portugal, USA, Mexico, Colombia, Brazil, Kenya, South Africa, Russia, Japan, Taiwan and Malaysia), accounting for a total of 12.4 trillion USD in revenue, for their commitment to the SDGs. Commitment ranged from simply mentioning the SDGs in reports (which was given a score of 1) to actually defining, measuring and linking KPIs to societal impacts (a score of 5). This Likert's scale approach yielded an average SDG-commitment score of a little over 2.7, which the authors feel needs to be improved over time.

SSE PLC is a leading energy services provider in the UK and Ireland. The company has identified five highly material SDGs $(7,8,9,12$ and 13$)$ with 15 targets and three second-tier SDGs (5, 10 and 15) in its annual report for 2017-18 (SSE, UK, 2019). Key performance indicators related to these targets for 2016-17 and 2017-18 enable one to measure the progress SSE PLC has made with respect to the SDGs, over the said 12-month period. The British firm adopts a Red-Amber-Green coding scheme to meas- ure performance against initially-set targets. As acknowledged in the Chemical Sector SDG roadmap published by World Business Council for Sustainable Development (WBCSD, 2018) (this sector belongs to the Industrial Products category), the chemical sector, by dint of its size, scope, scale and spread (4 trillion USD annual turnover, 20 million direct and indirect jobs, $10 \%$ of total global final energy demand, $7 \%$ of annual global greenhouse gas emissions, a wide customer base encompassing practically all the industrial sectors) can make meaningful contributions to 8 of the 17 SDGs. There exists a lot of leeway and latitude for corporates to identify relevant SDGs and targets and align them to their roles (or themes), to ensure that meaningful, manageable and measurable progress can be effectively made. The SDG framework, for corporates, is thus a veritable smorgasbord one can adeptly choose from - not merely to toe the line, but to contribute willingly to sustainable development.

In 2018, the British Academy issued a report which argued for the replacement of profit-focused shareholder capitalism with a system in which corporations embrace social purpose (The Economist, 3011-2019). It recommended the establishment of common standards for measuring social impact as an improvement over the current hotch-potch of competing and completely misleading measures of how firms fare on environmental, social and governance matters. The question to be answered then is if every company must by law have a purpose that is not solely about profit, would strategies that maximised profit become illegal unless they also solved poverty (SDG 1) and climate change (SDG 13). Here, a question raised by Hickel (2019) seems very pertinent Is economic growth (to which corporates contribute) to be looked upon as an end in itself or as a means towards ends which need to be better-defined? Hickel (2019) have also concluded, inter alia, that the only way to reconcile SDG 8 (economic growth) with SDG 12 (sustainable production and consumption) is through absolute decoupling of the material footprint from GDP; goading industries to keep improving their resource use efficiencies (which thanks to the entrenchment of the circular economy concept in some parts of the world, seems to be a goal worth pursuing). He however admits that permanent decoupling is impossible, let alone difficult; and believes that SDG 8 can perhaps never be reconciled with SDG 13 (Climate change).

\section{Catch 22s - how to prioritise?}

In Lynch et al. (2019) and Lafortune et al. (2019), all the indicators are assigned the same priority (weighting); and the same applies to all the SDGs factored in, into the index. Equi-weighting is tantamount to playing it safe, but does introduce uncertainties. On the other hand, reaching out to a handful of representative experts or even a sample of the 
general population for that matter, is also fraught with the same risk, even though none would dispute the fact that cognitive diversity - assembling people from different perspectives and intellectual backgrounds - is necessary if effective strategies need to be drawn up for sustainable development (Bartleby, 2019). However, it must be borne in mind that priorities change, as evidenced by the sudden spurt in the fraction of Americans who believe that global warming and climate change are realities which need to be taken seriously (thanks to the highly-destructive hurricanes and forest fires they have experienced this year); and this would necessitate rethinking the equiweighting approach. In a Chinese survey (sample size not known), $36 \%$ of respondents intended to reduce pork and red meat consumption, citing health (social), environmental and food safety (social) as reasons for the same, in that order. In Russia, as gathered from The Economist (21-09-2019), the worsening state of the environment came in ninth place, when Russians were asked to name their main concerns; whereas concerns about the economy (socioeconomic) and corruption (governance-related) dominated.

It would be naïve to set weighting factors now for instance and assume that they would be true for the next 10 years. Overcoming subjectivity of course, needless to say, entails more work, more data-gathering in order to align decisions as closely and faithfully as possible with the prevailing (and changing) realities. While on the theme of prioritising, Lafortune et al. (2019) contend that if peak GHG emissions need to happen in 2020 (this is eminently desirable of course), the focus on climate change cannot be done away with. Climate change threatens all, and undermines the capacity to address other sustainable development goals. The chain reactions which will be induced by climate change, will impact a whole lot of SDGs directly and indirectly. As Wright et al. (2016) have observed, climate change or the inability to meet SDG 13 in other words, will significantly hamper (constrain, counteract or cancel) the ability of least-developed countries to achieve the SDGs in poverty (1), hunger (2), health (3), water (6), growth (8), infrastructure (9), cities (11), marine resources (14) and ecosystems (15); while also making the achievement of the other SDGs challenging.

Using SDG indicator data (time series) for 227 countries, Pradhan et al. (2017) showed that among the top ten trade-off SDG pairs, SDG 12 (Responsible Consumption and Production) figures seven times, conflicting with SDGs 10 (I), 1 (II), 6 (III), 3 (IV), 4 (V), 5 (VII) and 2 (IX). Likewise, the paper also shows that SDG 1 (No poverty) figures five times in the top-ten synergistic SDG-pairs, positively influencing 4 (II), 5 (III), 10 (IV), 6 (V) and 3 (VIII). In the PwC report referred to earlier, for all the six sectors, SDG 13 - climate change - was accorded either top priority or put in second place by the companies, while SDG 8 - decent wok and economic growth figured among the top three for all of them.

Corporates tend to decide on the basis of what they can actually influence and control, the scope, span and scale of their activities, and it may be wise to let them do so and get closer and closer to the elusive target of socially-inclusive economic growth, with a strong element of circularity and environmentfriendliness embedded in it. There would inevitably be some primary SDGs and targets within them, which would slowly but surely enable the incorporation of the other targets and goals at a later stage (either before or after 2030).

\section{Learning, sharing and helping}

There is a message to people in general in Lynch et al. (2019). The buck cannot always be passed onto the decision-makers, bureaucrats and politicians. There is an undeniable need to impress upon those on the upper strata to willingly make sacrifices to make the top-down implementation successful. Bottom-up efforts thus must have an element of sacrifice in them. While those who are disadvantaged are slowly helped by policies to move up the socio-economic ladder, the top must be coaxed to sacrifice and move down a bit...in the interest of readjustment and reorganisation. Convincing the well-off of the benefits of a less lop-sided society will be indispensable, going forward.

In addition to comparisons among cities within the same State, cities in general, and among States, Lynch et al. (2019) also bring in comparisons with other OECD countries - to serve as benchmarks, the cities in the USA could adopt, and perhaps learn from by reaching out. US cities, it is learnt score poorly on the SDGs 2, 5, 7 and 9; and there is tremendous scope for partnerships with EU cities en route to sustainability. As far as the European cities go, Lafortune et al. (2019) point to goals which city administrations in the EU have set for themselves Copenhagen wishes to be the world's first carbonneutral city by 2025 , Stockholm is aiming for $100 \%$ renewable energy by 2040, while Amsterdam wishes to totally stop the use of natural gas by 2050 .

\section{Using power wisely}

While relevance and applicability for practical decision-making are cornerstone criteria for indicator selection, the interconnection among SDG indicators must also not be forgotten (Nilsson et al., 2016a). Explicit double-counting must be necessarily avoided, while it is advisable to also not overlook the implicit ones. Choosing only those indicators which are all positively correlated such that an improvement in one automatically results in an improvement in the others is not a good practice. As trade-offs and compromises are inevitable in sustainable development and must be transparent in analyses, the selec- 
tion of indicators must not be biased in any way in order to present a rosier picture of development. As Allen et al. (2019) have advised, given that the choice of indicators can greatly influence the results, it is important that a transparent, consistent, consultative and robust process is undertaken for indicator selection, drawing upon the advice of experts in each goal area.

\section{En passant - work to be done}

A motivating statement when it concerns possible research topics for the future is the observation of the fact that there is a paucity of internationally comparable data for cities vis-à-vis countries. It must also not be forgotten that changing one city provides the potential to change others. The implementation of SDGs at local levels will be fraught with challenges - different types in different cities at different times in the future. These challenges will include, among others, access to reliable data, policy relevance and political prioritisation, complexity, externalities, multi-level and multi-actor governance systems, financing, capacity and skills.

It is imperative for the sake of genuine sustainable development to appreciate and incontrovertibly agree that judged against the SDGs, all countries are developing countries. Therefore, what is needed now for any actor in the world is to conceive a new and different, truly universal concept of international cooperation for sustainable development that addresses all types of entities, rich and poor alike. In the modern world with all its complexities, cooperation is essential if breakthroughs are to be made. One can be inspired by the work done by the 2019 Nobel Economics laureates - Abhijit Banerjee, Ester Duflo and Michael Kremer. They shunned the high-theory approach which is the default favourite of economists, in favour of randomised trials, to understand the lessunderstood relationships among different aspects of (sustainable) development - healthcare, education, entrepreneurship, skills development etc.

Transformative change is needed to attain the SDGs and this, as proposed by Randers et al. (2015), is feasible with accelerated renewable energy growth, accelerated productivity in sustainable food chains, new development models in poor countries, unprecedented inequality reduction and investment in education for all, gender equality, health and family planning - all being prioritised equally and implemented simultaneously.

It goes without saying that implementing the SDGs may seem like fishing expeditions, but once the scope if defined and the goals are fixed in stone, success is bound to follow. After all, eventually, a rising tide will raise all ships, and an ebbing one will sink all of them.

\section{References}

1. ALLEN C., METTERNICHT G., WIEDMANNN T, 2018, Initial progress in implementing the Sustainable Development Goals (SDGs) -A review of evidence from countries, in: Sustainability Science, 13, p. 1453-1467.

2. BARTLEBY, 2019, Second thoughts, in: The Economist, October 12, 2019, Page 61, The Economist Newspapers Limited, London, United Kingdom.

3. CONVENTION FOR BIOLOGICAL DIVERSITY, 2019, Collection methodology for key performance indicators for smart sustainable cities, United 4 Smart Sustainable Cities, https://www.unece.org/fileadmin/ DAM/hlm/documents/Publications/U4SSC-CollectionMethodologyforKPIfoSSC-2017.pdf (1.09.2020).

4. HEEKS R., 2016, Examining 'Digital Development': The Shape of Things to Come?, in: Development Informatics Working Paper no. 64.

5. HICKEL J., 2019, The contradiction of the sustainable development goals: Growth versus ecology on a finite planet, in: Sustainable Development, 27(5), p. 873-884.

6. JONES P., WYNN M., HILLIER D., COMFORT D, 2017, The Sustainable Development Goals and Information and Communication Technologies, in: Indonesian Journal of Sustainability Accounting and Management, 1(1), p. 1-15.

7. KALLIO TJ., NORDBERG P., AHONEN A., 2007, Rationalising Sustainable Development - a critical treatise, in: Sustainable Development, 15, p. 41-51.

8. KLOKE-LESCH A., 2018, Why is the EU failing to champion the SDGs?, in: Journal of International Relations and Sustainable Development, 12, p. 144-159.

9. LAFORTUNE G., FULLER G., SCHMIDTTRAUB, G., ZOETEMAN, K., MUIDER R., DAGEVOS J., 2019, SDG Index and Dashboard report European cities, Sustainable Development Solutions Network - A Global Initiative for the United Nations and the Brabant Centre for Sustainable Development (Telos), https://www.sdgindex.org/reports/sdg-index -and-dashboards-report-for-european-cities/ (1.09.2020).

10. LYNCH A., LOPRESTI A., FOX C., 2019, The 2019 US Cities Sustainable Development Report. Sustainable Development Solutions Network - A Global Initiative for the United Nations, https://www.sustainabledevelopment.report/reports/2019-us-cities-sustai nable-development-report/ (1.09.2020).

11. NILSSON M., GRIGGS D., VISBECK M., 2016a, Map the interactions between Sustainable Development Goals, in: Nature, 534, p. 320-322.

12. NITI AAYOG, GOVERNMENT OF INDIA, 2018, SDG India Index - Baseline report 2018, https://niti.gov.in/content/sdg-india-index-baselinereport-2018 (1.09.2020)

13. PRADHAN P., RYBSKI D., KROPP J., 2017, A systematic study of sustainable development goal (SDG) interactions. Earth's, in: Future, 5, p. 1169-1179.

14. QUENTAL N., LOURENCO JM., DA SILVA FN., 2010, Sustainable development policy: goals, targets and political cycles, in: Sustainable Development, 19(1), p. 15-29. 
15. ROCKSTRÖM J., STEFFEN W., NOONE K., PERSSON Å., CHAPIN FS., LAMBIN E., LENTON T., SCHEFFER M., FOLKE C., SCHELLNHUBER HJ., NYKVIST B., DE WIT C., HUGHES T., VAN DER LEEEUW S., RODHE H., SORLIN S., SNYDER PK., CONSTANZA R., SVEDIN U., FALKENMARK M., KARLBERG L., CORELL R., FABRY V., HANSEN J., WALKER B., LIVERMAN D., RICHARDSON K., CRUTZEN P., FOLEY J., 2009, Planetary boundaries: Exploring the safe operating space for humanity, in: Ecology and Society, 14(2), p. 1-33.

16. SCOTT L., MCGILL A., 2018, SDG Reporting Challenge 2018: From promise to reality - Does business really care about the SDGs? Pricewaterhouse Coopers, https://www.pwc.com/sdgreportingchallenge, (1. 09.2020).

17. SSE, UK, 2018, Creating value in a sustainable way - SSE plc Sustainability Report 2018, https://sse.com/ media/522476/SSE-plc-Sustainability-Report-2018. pdf (1.09.2020)

18. STEFFEN W., RICHARDSON K., ROCKSTRÖM J., CORNELL SE., FETZER I., BENNET EM., BIGGS R., CARPENTER SR., DE VRIES W., DE WIT CA., FOLKE C., GERTEN D., HEINKE J., MACE GM., PERSSON LM., RAMANATHAN V., REYERS B., SÖRLIN S., 2015, Planetary bounda- ries: Guiding human development on a changing planet, in: Science, 347(6223), p. 736.

19. THE ECONOMIST, October 19, 2019, Trade and emissions - Out of sight, Page 70, in: The Economist Newspapers Limited, London, UK.

20. THE ECONOMIST, November 30, 2019, Companies and society - on purpose, Page 57, in: The Economist Newspapers Limited, London, UK.

21. THE ECONOMIST, September 21, 2019, Climate change - A warmer Russia, Pages 27-28, in: The Economist Newspapers Limited, London, United Kingdom

22. WORLD BUSINESS COUNCIL FOR SUSTAINABLE DEVELOPMENT, 2018, Chemical Sector SDG Roadmap, https://www.wbcsd.org/Programs/ People/Sustainable-Development-Goals/Resources/ Chemical-Sector-SDG-Roadmap (1.09.2020).

23. WRIGHT H., REEVES J., HUQ S., 2016, Impact of climate change on LDCs : are the SDGs possible? IIED Briefing, May, http://pubs.iied.org/17298IIED, (1.09.2020).

24. ZINKERNAGEL R., EWANS J., NEIJ L., 2018, Applying the SDGs to cities: Business-as-usual or a new dawn?, in: Sustainability, 10,p. 3201.

25. ZONDERVAN R., 2017, The scientific and technological community in the Sustainable Development Goal process, in: Environmental Scientist, 26(3), p. 34-38. 
